\title{
Development of a TaqMan qPCR protocol for detecting Acipenser ruthenus in the Volga headwaters from eDNA samples
}

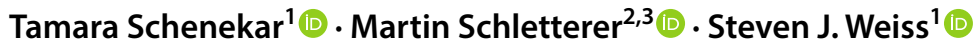

Received: 16 September 2019 / Accepted: 2 January 2020 / Published online: 9 January 2020

(c) The Author(s) 2020

\begin{abstract}
A recent eDNA-metabarcoding study assessing fish diversity in the Upper Volga catchment did not detect sterlet at any of the sampled stretches, despite recent sightings that suggest its presence. We designed a TaqMan qPCR protocol to test for sterlet in selected eDNA samples from that study. In-silico and in-vitro tests confirm the protocol's high sensitivity and specificity to sturgeon taxa and potentially paddlefishes. Using this assay, sterlet were not detected in 26 eDNA samples from the Volga headwaters, agreeing with the metabarcoding results.
\end{abstract}

Keywords Sterlet $\cdot$ Environmental DNA $\cdot$ Sturgeon $\cdot$ Freshwater monitoring $\cdot$ Real-time PCR $\cdot$ Endangered species

Assessing presence and distribution of freshwater species using environmental DNA (eDNA) is developing into a powerful conservation management tool (Deiner et al. 2017; Ruppert et al. 2019). Taxon-specific qPCRs are widely used to assess fish presence (e.g. Carim et al. 2016; Jensen et al. 2018; Roy et al. 2018) and can be more sensitive than metabarcoding (Harper et al. 2018). The sterlet Acipenser ruthenus is listed as vulnerable by the IUCN with a decreasing population trend. Main threats involve habitat fragmentation and loss and overexploitation (IUCN 2019). Using an eDNA-metabarcoding approach, Lecaudey et al. (2019) identified 23 fish species in the Upper Volga catchment. However, the sterlet, a species of conservation interest in this area (Schletterer 2006; Schletterer et al. 2018), was not detected.

To evaluate the metabarcoding results, we designed a TaqMan-qPCR assay to detect sterlet from environmental

Electronic supplementary material The online version of this article (https://doi.org/10.1007/s12686-020-01128-w) contains supplementary material, which is available to authorized users.

Tamara Schenekar

tamara.schenekar@uni-graz.at

Institute of Biology, University of Graz, Graz, Austria

2 Institute of Hydrobiology and Aquatic Ecosystem Management, BOKU - University of Natural Resources and Life Sciences, Vienna, Austria

3 TIWAG - Tiroler Wasserkraft AG, Innsbruck, Austria samples. Other sturgeon qPCR protocols (Farrington and Lance 2014; Bergman et al. 2016; Pfleger et al. 2016; Yusishen et al. 2018) focused on North American species and were optimized on the respective local fish community. We designed TaqMan primers (AruF: 5'-TCTACCGTCACC CAGGTCAT-3'; AruR: 5'-CGCCTGTTAAGGTTGTGT TCTTTT-3') and probe (AruPr: 5'-FAM-GAGAGGTAC AGCTCTCTTG-MGB-Q500-3') in the 16S rRNA gene using the DECIPHER package (Wright et al. 2014; Wright 2015). We utilized the reference database of Lecaudey et al. (2019) containing 150 sequences of 45 native and invasive fishes, covering 19 Palearctic fish families, including sterlet and Russian sturgeon A. gueldenstaedtii (Supplemental 1). Primers and probe were quality-checked with MultiplePrIMERANALYZER (Thermo Fisher Scientific). For in-silico assay testing, we performed a PrIMERBLAST search (Ye et al. 2012) yielding most significant hits with Acipenser sp. (up to 1 mismatch), with best hits on the target species, A. ruthenus (no mismatch). There were two additional hits (2 mismatches in the forward primer) for beluga (Huso huso) and American paddlefish (Polyodon spathula). Both of these latter species do not occur in our study area (IUCN 2019). Furthermore, sterlet is the only Acipenser species currently occurring in the Upper Volga (Schletterer et al. 2018), therefore, a positive signal would indicate this species' presence. Primer and probe concentrations were optimized via a qPCR reaction-series using sterlet tissue extract (approx. $20 \mathrm{ng}$ / $\mu \mathrm{l})$ as template, varying both primer concentrations from 200 to $800 \mathrm{nM}$ (in $200 \mathrm{nM}$ steps) and probe concentrations 
Table 1 Details on the locations of eDNA samples tested for sterlet with the newly developed protocol

\begin{tabular}{lllll}
\hline River & Location & GPS coordinates & Sampling date & $\begin{array}{l}\text { Number of } \\
\text { eDNA samples } \\
\text { tested }\end{array}$ \\
\hline Volga & Staritsa & $56^{\circ} 30^{\prime} 44.1^{\prime \prime} \mathrm{N} 34^{\circ} 55^{\prime} 33.2^{\prime \prime} \mathrm{E}$ & 13.08 .2017 & 3 \\
Volga & Rzhev & $56^{\circ} 15^{\prime} 31.7^{\prime \prime} \mathrm{N} 34^{\circ} 19^{\prime} 12.2^{\prime \prime} \mathrm{E}$ & 13.08 .2017 & $8^{\mathrm{a}}$ \\
Volga & Tver Migalovo & $56^{\circ} 50^{\prime} 53.7^{\prime \prime} \mathrm{N} 35^{\circ} 46^{\prime} 40.9^{\prime \prime} \mathrm{E}$ & 17.08 .2017 & 3 \\
Tudovka & Molodoy Tud & $56^{\circ} 25^{\prime} 16.9^{\prime \prime} \mathrm{N} 33^{\circ} 36^{\prime} 28.4^{\prime \prime} \mathrm{E}$ & 13.08 .2017 & 4 \\
Tvertsa & Mel'nikovo & $56^{\circ} 56^{\prime} 35.0^{\prime \prime} \mathrm{N} 35^{\circ} 47^{\prime} 00.1^{\prime \prime} \mathrm{E}$ & 18.08 .2017 & $8^{\mathrm{a}}$ \\
\hline
\end{tabular}

Details on sampling protocol are given in Supplemental 4

${ }^{a}$ Locations with recently documented sterlet presence (Supplemental 5). Therefore, all available eDNA samples were surveyed from 100 to $400 \mathrm{nM}$ (in $100 \mathrm{nM}$ steps). Final qPCR reactions consisted of $10 \mu \mathrm{l} 2 \mathrm{x}$ TaqMan Environmental Master Mix 2.0 (Thermo Fisher Scientific), $800 \mathrm{nM}$ of forward and reverse primer, respectively, $200 \mathrm{nM}$ of probe, $2 \mu \mathrm{l}$ template and $\mathrm{ddH}_{2} \mathrm{O}$ up to a final volume of $20 \mu \mathrm{l}$. A standard curve was generated for assay efficiency evaluation (from $10^{9}$ to $10^{0}$ copies/ $\mu$ l, six replicates each), showing a limit of quantification at $10^{4}$ copies/ $\mu$ l, a limit of detection at $10^{3}$ copies/ $\mu \mathrm{l}$, an $\mathrm{R}^{2}$-value of 0.998 and a reaction efficiency of $99.6 \%$ (Supplemental 2). For in-vitro testing, we ran qPCRs on tissue extracts from four sturgeons (A. ruthenus, A. sturio, A. gueldenstaedtii and A. baerii), and eight teleost species from six families (Anguilla anguilla, Ballerus ballerus, Ballerus sapa, Leuciscus aspius, Cobitis sp., Salmo trutta, Silurus glanis, Thymallus thymallus). Cycling conditions consisted of an initial denaturation of $95{ }^{\circ} \mathrm{C}$ for $10 \mathrm{~min}$ followed by 50 cycles of $95^{\circ} \mathrm{C}$ for $15 \mathrm{~s}$ and $60^{\circ} \mathrm{C}$ for $1 \mathrm{~min}$, performed on a Corbett Rotor-Gene RG-3000 (Qiagen) in standard speed mode. Amplification was observed for Acipenser species only. For in-situ verification, we sampled five fish tanks of a local hatchery and pet shop harboring three different Acipenser species (Supplemental 3). All fish-tank eDNA samples showed positive amplification in all PCR replicates and Sanger sequencing confirmed amplification of only target species.

Finally, we assayed 26 samples from five locations collected by Lecaudey et al. (2019) (Table 1, Supplemental 4). In the Upper Volga, sterlet is present in the Ivankovskoe and Uglich reservoirs (Supplemental 5). Formerly common in the Volga headwaters (Grazianov 1907), the sterlet is reported by anglers to be rare upstream of Tver. In August 2005, sterlet was documented 50-100 km upstream of Rzhev (Schletterer 2006) and in 2016, they were stocked in the Tvertsa River (Supplemental 5).

No amplification was observed from any eDNA samples corroborating the results of Lecaudey et al. (2019). The non-detection could be caused by seasonal migrations during summer months (Kubala et al. 2019, Sorokin et al. 2002), orvery low abundances ("rarely caught andin single instances"-Sorokin et al. 2002), that may have led to
eDNAconcentrations below the detection threshold of the assay. One sampling replicate consisted of $250 \mathrm{ml}$ of filtered water and replicates were kept separate for analyses. This volume falls below generally recommended sample volumes (e.g. Wilcox et al. 2018) and might have led to a very low sterlet DNA concentration in the individual extractions (elution volume $100 \mu \mathrm{l}$ each). We therefore recommend a larger filtered water volume $(>1$ l) per sampling replicate when applying this protocol for a scarce species such as sturgeon in large lowland rivers.

The main intention of this assay was to detect sterlet in the headwaters of the Volga, excluding cross-amplification from teleosts and lampreys. In-silico and in-vitro tests show that it will also detect other Palearctic Acipenser species and potentially the two Huso species. This assay might also be suitable for detecting other Palearctic sturgeon species, but would need further testing for specificity and sensitivity.

Acknowledgements Open access funding provided by University of Graz. We thank Alexander Ruchin, Thomas Friedrich, Lukas Zangl, and Stephan Koblmüller for provision of tissue samples and the local Waldschach hatchery, as well as a local pet shop for providing water samples from their sturgeon tanks. Special thanks also go to Laurène Lecaudey for extraction of the Russian eDNA samples. This work was financed by the VÖU (Verein für Ökologie und Umwelt), in the framework of the project "Single species targeting via qPCRs in fish monitoring in the headwaters of the Volga river using eDNA - SSqeDNA".

\section{Compliance with ethical standards}

Conflict of interest The authors declare that they have no conflict of interest.

Open Access This article is licensed under a Creative Commons Attribution 4.0 International License, which permits use, sharing, adaptation, distribution and reproduction in any medium or format, as long as you give appropriate credit to the original author(s) and the source, provide a link to the Creative Commons licence, and indicate if changes were made. The images or other third party material in this article are included in the article's Creative Commons licence, unless indicated otherwise in a credit line to the material. If material is not included in the article's Creative Commons licence and your intended use is not permitted by statutory regulation or exceeds the permitted use, you will 
need to obtain permission directly from the copyright holder. To view a copy of this licence, visit http://creativecommons.org/licenses/by/4.0/.

\section{References}

Bergman PS, Schumer G, Blankenship S, Campbell E (2016) Detection of adult green sturgeon using environmental DNA analysis. PLoS ONE 11:1-8. https://doi.org/10.1371/journal.pone.0153500

Carim KJ, Dysthe JCS, Young MK et al (2016) An environmental DNA assay for detecting arctic grayling in the upper Missouri River basin, North America. Conserv Genet Resour 8:197-199. https:// doi.org/10.1007/s12686-016-0531-1

Deiner K, Bik HM, Mächler E et al (2017) Environmental DNA metabarcoding: transforming how we survey animal and plant communities. Mol Ecol 26:5872-5895. https://doi.org/10.1111/ mec. 14350

Farrington HL, Lance RF (2014) Development of genetic markers for environmental DNA (eDNA) monitoring of sturgeon. Ecosyst Manag Restor Res Progr.https://doi.org/10.13140/2.1.1330.6248

Grazianov VI (1907) A synoptic essay of the taxonomy and geography of the fishes of the Russian Empire. Trudy Ikhtio Rus Obs Akkl Zhivost, Moksha

Harper LR, Lawson Handley L, Hahn C et al (2018) Needle in a haystack? A comparison of eDNA metabarcoding and targeted qPCR for detection of the great crested newt (Triturus cristatus). Ecol Evol 8:6330-6341. https://doi.org/10.1002/ece3.4013

IUCN (2019) The IUCN red list of threatened species. Version 2019-2. http://www.iucnredlist.org. Accessed 16 Dec 2019

Jensen MR, Knudsen SW, Munk P et al (2018) Tracing European eel in the diet of mesopelagic fishes from the Sargasso Sea using DNA from fish stomachs. Mar Biol 165:1-11. https://doi.org/10.1007/ s00227-018-3390-3

Kubala M, Farský M, Pekárik L (2019) Migration patterns of sterlet (Acipenser ruthenus, Linnaeus 1758) in the Middle Danube assessed by 1 year acoustic telemetry study. J Appl Ichthyol 35:54-60. https://doi.org/10.1111/jai.13859

Lecaudey L, Schletterer M, Kuzovlev VV et al (2019) Fish diversity assessment in the headwaters of the Volga River using environmental DNA metabarcoding. Aquat Conserv Mar Freshw Ecosyst 29:1785-1800. https://doi.org/10.1002/aqc.3163

Pfleger MO, Rider SJ, Johnston CE, Janosik AM (2016) Saving the doomed: using eDNA to aid in detection of rare sturgeon for conservation (Acipenseridae). Glob Ecol Conserv 8:99-107. https ://doi.org/10.1016/j.gecco.2016.08.008

Roy M, Belliveau V, Mandrak NE, Gagné N (2018) Development of environmental DNA (eDNA) methods for detecting high-risk freshwater fishes in live trade in Canada. Biol Invasions 20:299314. https://doi.org/10.1007/s10530-017-1532-z

Ruppert KM, Kline RJ, Rahman MS (2019) Past, present, and future perspectives of environmental DNA (eDNA) metabarcoding: a systematic review in methods, monitoring, and applications of global eDNA. Glob Ecol Conserv 17:1-29. https://doi. org/10.1016/j.gecco.2019.e00547

Schletterer M (2006) Biological assessment on the Upper Volga River. In: Schletterer M, Kuzovlev VS (eds) Proceedings of freshwater research: Upper Volga expedition 2005: technical report. DAV, pp 76-126

Schletterer M, Kuzovlev VV, Zhenikov YN et al (2018) Fish fauna and fisheries of large European rivers: examples from the Volga and the Danube. Hydrobiologia 814:45-60. https://doi.org/10.1007/ s10750-017-3370-5

Sorokin AS (2002) Krasnaya kniga Tverskoi oblasti (Red Book of the Tver Oblast). OOO Veche Tveri, OOO Izdat, Tver

Wilcox TM, Carim KJ, Young MK et al (2018) Comment: the importance of sound methodology in environmental DNA sampling. N Am J Fish Manag 38:592-596. https://doi.org/10.1002/ nafm. 10055

Wright ES (2015) DECIPHER: harnessing local sequence context to improve protein multiple sequence alignment. BMC Bioinform.https://doi.org/10.1186/s12859-015-0749-z

Wright ES, Yilmaz LS, Ram S et al (2014) Exploiting extension bias in PCR to improve primer specificity in ensembles of nearly identical DNA templates. Environ Microbiol 16:1354-1365

Ye J, Coulouris G, Zaretskaya I et al (2012) Primer-BLAST: a tool to design target-specific primers for polymerase chain reaction. BMC Bioinform 13:134

Yusishen ME, Eichorn F-C, Anderson WG, Docker MF (2018) Development of quantitative PCR assays for the detection and quantification of lake sturgeon (Acipenser fulvescens) environmental DNA. Conserv Genet Resour 0:0. https://doi.org/10.1007/s1268 6-018-1054-8

Publisher's Note Springer Nature remains neutral with regard to jurisdictional claims in published maps and institutional affiliations. 